\title{
DIVERSION, PUNISHMENT AND RESTRICTING HUMAN RIGHTS
}

\author{
Gavin Dingwall, Reader in Law, De Montfort University and \\ Laurence Koffman, Reader in Law, Sussex University
}

\section{Introduction}

There are sound reasons, in terms of both policy and criminological thinking, for diverting young offenders who commit comparatively trivial offences from the criminal courts. Indeed, so well accepted is this principle that it has been recognised in Rule 11 of the United Nations Standard Minimum Rules for the Administration of Juvenile Justice. ${ }^{1}$ Traditionally, the mechanism for achieving this in England and Wales was through the administering of a caution by a senior police officer. Whilst this process was well established in practice, and also the subject of a number of Home Office circulars, it lacked any statutory basis. ${ }^{2}$

This informal system of diversion was reformed by the Crime and Disorder Act 1998. The New Labour government was keen to avoid the accusation, levelled at previous Labour administrations, that it was "soft" in its approach to juvenile crime. ${ }^{3}$ Under its flagship 1998 legislation, the government wanted to show that it was not prepared to excuse youth crime on the basis of social disadvantage and relative immaturity, but instead that it wished to emphasise the impact of youth offending on victims and local communities. As part of these youth justice reforms, the new government significantly altered the mechanism for diverting juveniles who commit minor offences. This was motivated by a belief, ${ }^{4}$ which was far from universally shared, ${ }^{5}$ that "[inconsistent], repeated and ineffective cautioning has allowed some

1 General Assembly Resolution 40/33 (1985), Rule 11.1: "Consideration shall be given, wherever appropriate, to dealing with juvenile offenders without resorting to formal trial by the competent authority, referred to in Rule 14.1 below."

2 See further Dingwall and Harding, Diversion in the Criminal Process (1998), Chap.7. There had been arguments that cautioning should be given a statutory basis; see May, "The Legal Effect of a Police Caution" [1997] Criminal Law Review 491.

3 See Butler and Drakeford, "Tough Guise: the Politics of Youth Justice" (1997) 44(4) Probation Journal 216. Also, Windlesham, Dispensing Justice: Responses to Crime, Vol. 4 (2001), Chap.3.

4 See further Home Office, Tackling Youth Crime (1997) and Home Office, No More Excuses - A New Approach to Tacking Youth Crime in England and Wales (1997).

5 See Antonopoulos and Winterdyk, "The British 1998 Crime and Disorder Act: a "Restorative" Response to Youth Offending?" (2003) 11(4) European Journal of Crime, Criminal Law and Criminal Justice 386; Bateman, "Living with Final Warnings: Making the Best of a Bad Job?" (2003) 2(3) Youth Justice 131; Evans and Puech, "Reprimands and Warnings: Popular Punitiveness or Restorative Justice?" [2001] Criminal Law Review 794; Fionda, "Crime and Disorder Act 1998: New Labour, Old Hat: Youth Justice and the Crime and Disorder Act 1998" [1999] Criminal Law Review 36 and Gelsthorpe and Morris, "Much Ado about Nothing - A Critical Comment on Key Provisions Relating to Children in the Crime and Disorder Act 1998" (1999) 11 Child and Family Law Quarterly 209. 
children and young people to feel that they can offend with impunity" ${ }^{6}$ Cautioning was replaced by a new statutory system for diverting children and young people from the court system. ${ }^{7}$ This new scheme allowed the police to issue reprimands or warnings if certain, prescribed conditions were met. ${ }^{8}$ The system was more invasive in that, if a warning was given, the case would be assessed by a youth offending team which would design a suitable rehabilitative programme for the offender, unless the team believed this to be

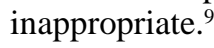

At the same time as it was radically overhauling the juvenile justice system, and introducing other measures which have been criticised as inconsistent with the protection of civil liberties, ${ }^{10}$ the Government claimed to be "bringing rights home" with its enactment of the Human Rights Act 1998. ${ }^{11}$ This legislation was introduced with the specific aim of incorporating the European Convention on Human Rights (hereafter the ECHR) into domestic law. It might have been hoped that the combined effect of incorporating the ECHR into domestic law and introducing a new statutory diversionary system would have been to increase the protection of the human rights of young offenders. However, there were some concerns, even at the time the Act was passed, that this might not be the case. For example, the new scheme of reprimands and warnings did little to address a central problem of the old cautioning system, namely that it bestowed too much discretion upon the police in determining both the guilt of a suspect and the imposition of a sanction. ${ }^{12}$ The combination of this concentration of power in the hands of the police with an absence of safeguards for young suspects was a major weakness of the old cautioning system, and this was not eradicated by the new legislation. A further concern was that, under the old system, the consent of the juvenile suspect and his or her parents was required before a caution could be administered. In contrast, the 1998 Act contains no explicit requirement of consent.

\section{Loss of a Right to a Fair Trial?}

These initial concerns about the fairness of the new system of reprimands and warnings were brought into sharper focus by the recent decision of the House of Lords in $R$ (on the application of $R$ ) v Durham Constabulary and

6 Home Office, No More Excuses - A New Approach to Tackling Youth Crime in England and Wales (1997), para.5.10. Although the white paper acknowledged in para.5.9 that $68 \%$ of offenders who were cautioned for the first time were not cautioned again or reconvicted within two years.

7 Cautioning was retained for adult offenders. Part 3 of the Criminal Justice Act 2003 additionally introduced 'conditional cautioning' for adult offenders.

8 The Crime and Disorder Act, s.65.

9 ibid., s.66(2).

10 E.g. see Ashworth, "Social Control and Anti-Social Behaviour: The Subversion of Human Rights" (2004) 120 Law Quarterly Review. 263; Reid, "Anti-Social Behaviour Orders: Some Current Issues" (2002) 24(2) Journal of Social Welfare and Family Law 205; Hopkins Burke and Morrill, "Anti-Social Behaviour Orders: an Infringement of the Human Rights Act 1998?" (2002) 11(2) Nottingham Law Journal 1 and White, "Anti-Social Behaviour Orders Under Section 1 of the Crime and Disorder Act 1998" (1999) 24 European Law Review 55.

11 See Home Office, Rights Brought Home: the Human Rights Bill (1997).

12 E.g. see Leng et al, The Crime and Disorder Act 1998 (1998), p.76. 
another. ${ }^{13}$ In this case, the claimant was accused of indecently assaulting a number of girls at his school when he was 14 years old, leading to his suspension (and eventual expulsion) from the school. The claimant attended a police station where he admitted acts which amounted in law to indecent assault, but which he described as "horseplay". ${ }^{14}$ The police decided not to prosecute, but instead to issue a final warning under the Crime and Disorder Act 1998. Section 65(1) sets out the circumstances in which a reprimand or a warning can be given as follows:

"Subsections (2) to (5) below apply where - (a) a constable has evidence that a child or young person ("the offender") has committed an offence; (b) the constable considers that the evidence is such that, if the offender were prosecuted for the offence, there would be a realistic prospect of his being convicted; (c) the offender admits to the constable that he committed the offence; (d) the offender has not previously been convicted of an offence; and (e) the constable is satisfied that it would not be in the public interest for the offender to be prosecuted."

The warning was at first accepted by the claimant and his stepfather, who was present at the police interview in his capacity as an "appropriate adult", ${ }^{15}$ and was duly administered by the police. However, in contravention of the Home Office guidance for the police on the final warning scheme, ${ }^{16}$ neither the claimant nor his stepfather was told that the former would have to register with the police for inclusion on the sex offenders register. ${ }^{17}$ This consequence of receiving a warning did not become known to the claimant or his stepfather until about a week later. The claimant challenged the legality of the warning, arguing that the procedure had contravened his right, under Article 6 of the ECHR, to a fair and public hearing by an independent and impartial tribunal.

The Divisional Court ${ }^{18}$ held that the procedure had given rise to a breach of Article 6 and ordered the warning to be quashed. Central to the Divisional

13 [2005] 2 All ER 369.

14 ibid., at 377.

15 S.65(5) states that a reprimand or warning has to be given in the presence of an "appropriate" adult if the "offender" is under the age of 17. For the purposes of this section, s.65(7) defines "appropriate" adult as "(a) his parent or guardian or, if he is in the care of a local authority or voluntary organisation, a person representing that authority or organisation; (b) a social worker of a local authority social services department; (c) if no person falling within paragraph (a) or (b) above is available, any responsible person aged 18 or over who is not a police officer or a person employed by the police".

16 Home Office, Final Warning Scheme - Guidance for Police (2000), para.73 provides that the officer giving the warning should, amongst other matters, "make it clear" that "if the offence is one covered by the Sex Offenders Act 1997, the young person is required to register with the police for inclusion on the sex offenders register".

17 Sex Offenders Act 1997, Part 1. For further comment see Powers, "The Crime and Disorder Act 1998: Sex Offenders, Privacy and the Police" [1999] Criminal Law Review 3.

${ }_{18} R$ (on the application of $U$ ) $\mathrm{v}$ Metropolitan Police Commissioner, $R$. (on the application of R.) v Durham Constabulary [2003] All ER 419. 
Court's reasoning was a belief that the procedure adopted had the effect of publicly pronouncing the claimant guilty of indecent assault. The court stated that in this case (and that of a similar claimant):

"Although the decision was taken not to prosecute, the claimants were required to subject themselves to a procedure which had the effect of publicly pronouncing their guilt of the offence of indecent assault. That was the consequence of the final warnings being recorded on the PNC [police national computer], so that the fact of the final warnings became available not only in the event of future offending, but also to all those who have access to the PNC. It seems to us that these consequences prima facie constituted a breach of art 6(1) and (2). The claimants were denied a right to a trial of the charges against them, and declared guilty by an administrative process." 19

The consequences of the Divisional Court's decision were potentially farreaching, and it was not surprising that the Chief Constable of Durham and the Home Secretary chose to appeal. The 1998 legislation had not specified that the informed consent of the suspect was required before a warning could be given, but the Divisional Court appeared to have introduced such a requirement if the new warning scheme was not to be in breach of Article 6 . The House of Lords reversed the decision, ${ }^{20}$ holding that the final warning given to the claimant did not involve the determination of a criminal charge for the purposes of Article 6 of the ECHR. Once a decision not to prosecute had been made, a criminal charge (or the possibility of a charge) no longer existed:

"[The] criminal charge ceased to exist when a firm decision was made not to prosecute. For good and understandable reasons, the protection given to criminal defendants by art 6 covers not only the trial itself but extends back to the preparatory and preliminary processes preceding trial and forwards to sentence and appeal. But the primary focus of the right is the trial itself, because that is the stage at which guilt is decided with the possibility of condemnation and punishment. I find it hard to see how a criminal charge can be held to endure once a decision has been made that rules out the possibility of any trial, or condemnation, or punishment." 21

It was held that the process involved no decision in relation to any criminal charge, as the police officer only had to decide whether it was in the public interest for the offender to be warned rather than prosecuted, and he did not have to determine whether the claimant was guilty. The House also held that the possibility of punishment was crucial. As the process in the instant case

19 ibid., at 432.

20 Though it should be noted that Lord Steyn did so "reluctantly" [2005] 2 All ER 369 at 386, and Lady Hale did so with "considerable misgivings" [2005] 2 All ER 369 at 395.

21 ibid., at 379, per Lord Bingham. 
did not, in its opinion, ${ }^{22}$ involve the imposition (or possible imposition) of any punishment on an offender, it could not be regarded as the determination of a criminal charge. It drew a distinction between a process which could only result in measures of a preventive, rehabilitative, or welfare nature, and the determination of a criminal charge which would normally carry the possibility of punishment. ${ }^{23}$ Crucially, the House of Lords did not regard the recording of the warning on the police national computer, and the claimant's inclusion on the sex offenders register, as a determination or public declaration of the claimant's guilt, as access to these databases is controlled and limited.

\section{Punishment and Warnings}

In reaching its conclusion in the Durham Constabulary case, the House of Lords made two important determinations. First, it was held that there was no longer a criminal charge in existence once a decision had been made "that rules out the possibility of any trial, or condemnation, or punishment". ${ }^{24}$ In this case, once a decision had been made to issue a warning, there clearly was no possibility of a subsequent trial. The second determination that the House made was that the process did not involve any degree of condemnation or punishment. ${ }^{25}$ It is worth considering this point further.

Did the issuing of a warning involve "public condemnation"? In contrast to a conviction in a criminal court, it could be argued that the warning was not public in the sense that the individual's guilt would not be publicised immediately to the general public. However, it could be contended that the circumstances were such that the process amounted to the equivalent of a public declaration of guilt. It will be recalled that the Divisional Court held that the process involved a "public condemnation" for two reasons. The first of these is that, if the individual offended again, the existence of the warning would be made known to the court. The second is that the warning was accessible to all those with access to the Police National Computer, a group sufficiently large to have the effect of making the warning "public". In the House, there was some disagreement as to the number of individuals who had access to the information, but there was agreement that the procedure did not amount to a "public condemnation". Lord Bingham stated that the process was "far from a public announcement or declaration of guilt", as

22 Although Lady Hale noted at 394 that "[The claimant] and many others might consider it punitive. He faces a higher penalty should he offend again, he must notify the police of his whereabouts for some time, and his details are on a computer to which a very large number of people have access, albeit under carefully controlled circumstances".

23 Although the exact wording used by Lord Bingham at 381 is intriguing: "[The] determination of a criminal charge, to be properly so regarded, must expose the subject of the charge to the possibility of punishment, whether in the event punishment is imposed or not. A process which can only culminate in measures of a preventive, curative, rehabilitative or welfare-promoting kind will not ordinarily be the determination of a criminal charge." [Emphasis added]. Does this mean that, in contradiction of the first sentence, there are circumstances where punishment is not a necessity?

24 ibid., at 379, per Lord Bingham.

25 ibid., at 381 . 
access was limited to a "relatively small number of authorised people". ${ }^{26}$ Lady Hale, whilst agreeing that "[this] is not the public pronouncement of guilt which the Divisional Court thought it to be", nonetheless commented that "a very large number of people" had access to the information. ${ }^{27}$ Presumably Lady Hale would have deemed the process to involve "public condemnation" only if the information on the sex offenders register was available to the general public, as is the practice in some states in the USA.

It is clear then that, in contrast to the Divisional Court, the House of Lords adopted a narrow conception of "public condemnation". Similarly, their Lordships' finding that the process involved no degree of punishment was based on a very restrictive interpretation of punitiveness. There is a considerable literature, much of it of a philosophical nature, devoted to the meaning of punishment, ${ }^{28}$ and it is understandable perhaps that their Lordships were reluctant to get drawn into a prolonged discussion of this subject. However, their failure to explore the issue more fully was disappointing, and lends weight to previous academic criticism levelled at the British courts for their unsatisfactory view of what is "punitive". ${ }^{29}$ There have been other occasions on which courts have interpreted punishment restrictively for the purposes of the ECHR, and the House may have considered itself constrained by jurisprudence from the European Commission of Human Rights, ${ }^{30}$ the European Court of Human Rights ${ }^{31}$ and domestic courts. ${ }^{32}$ These courts have all, rather simplistically, assessed whether or not a measure is punitive by considering its primary purpose. (For example, it has been held, that registration on the sex offenders register is not punitive because the primary reason behind the scheme is public protection). ${ }^{33}$ Accordingly, it might be claimed that the reprimands and warnings scheme's primary rationale is that it is diversionary, aiming to keep young offenders away from the formal (and potentially harmful) processes of prosecution, trial and sentencing. It is also the case that this diversion of the young person does not involve any immediate imposition of a sanction upon the offender. However, this argument ignores the fact that reprimands and

26 ibid., at 384.

27 ibid., at 394.

28 A useful starting point for defining punishment is Hart, Punishment and Responsibility (1968), pp.4-5. For an interesting discussion of the "shared conception" of punishment, see Walker, Why Punish? (1991), pp.1-3. A useful overview of the subject can be found in Zedner, Criminal Justice (2004), Chap.3. Also see Lacey, State Punishment: Political Principles and Community Values (1988).

29 See Ashworth, op. cit., n.10.

30 Ibbotson v UK (1999) 27 EHRR CD 332; Adamson v UK (1999) 28 EHRR CD 209; and Porter v UK (2003) 37 EHRR CD 8.

31 Raimondo v Italy (1994) 18 EHRR 237.

32 B v Chief Constable of the Avon and Somerset Constabulary [2001] 1 All ER 562; Porter v Magill [2001] UKHL 67; $R$ (on the application of $S$ ) v Chief Constable of South Yorkshire Police, $R$ (on the application of Marper) v Chief Constable of South Yorkshire Police [2004] UKHL 39; $R$ (on the application of McCann) v Crown Court at Manchester, Clingham v Kensington and Chelsea Royal London $B C$ [2002] UKHL 39; $R$ (on the application of $M$ ) v Inner London Crown Court [2003] EWHC 301 (admin); $R$ v Field, $R$ v Young [2002] EWCA Crim 2913; and S. v Miller 2001 SC 977.

33 Ibbotson v UK (1999) 27 EHRR CD 332. 
warnings are recorded, and that this process might have serious adverse consequences for recipients, in terms of their future prospects (such as employment), and their future disposal within the criminal justice system should they offend again. The primary rationale of diversion might be that of keeping first-time young offenders out of court, and perhaps preventing their future offending, but at what point are the consequences of being reprimanded or warned so serious as to engage their rights to a fair trial under the ECHR? ${ }^{34}$

The Article 6 authorities, it is submitted, are of limited usefulness when it comes to defining punishment. In Engel v Netherlands (No. 1), ${ }^{35}$ it was held that three criteria should be considered in order to determine whether or not there was a "criminal charge" for the purposes of Article 6. First, the court should consider how the allegation is classified in domestic law. Then, consideration should be given to the nature of the offence. Finally, an assessment should be made of the severity of any potential punishment. In Garyfollou $A E B E$ v Greece, ${ }^{36}$ it was established that, in making such a determination, courts should treat these criteria as alternatives, unless this initial analysis proves inconclusive, in which case a cumulative approach may be adopted.

The potential severity of a measure or sanction may be central to a court's assessment of whether a "criminal charge" exists for the purposes of Article $6 .{ }^{37}$ However, in the Durham Constabulary case, this was not regarded as determinative of the issue. Their Lordships did not dispute the fact that there was a criminal charge initially, but took the view that this ceased to exist when the decision to issue a warning was taken. This article challenges this conclusion for the reasons outlined earlier, as have other commentators. ${ }^{38}$ The third criterion in Engel, though, is not the specific reason for our criticism of the House of Lords' decision. It is accepted that ECHR jurisprudence requires a measure to be highly punitive for this criterion to override the other two ${ }^{39}$ and that a warning may not reach this threshold. However, an assessment of a measure's punitiveness suggests that it involves some degree of punishment. Therefore, the issue appears to be one of quantification, rather than definition. A review of decisions relating to Article 7 might have proved more fruitful. Article 7, which provides a right to be free from retroactive penal provisions, requires consideration of what constitutes a "penal provision". This shifts the focus away from quantification, and towards definition. As was noted above, the jurisprudence suggests that whether a measure amounts to a "penal provision" should be decided with regard to its primary rationale. ${ }^{40}$

34 See Ashworth's commentary on $R$ (on the application of $R$ ) $\mathrm{v}$ Durham Constabulary [2006] Crim L $R 87$ at 88.

35 (1976) 1 EHRR 647 at para.82.

36 (1999) 28 EHRR 344 at para.33. See also Lauko v Slovakia [1999] EHRLR 105.

37 For further discussion, see Ashworth, op. cit., n.10, at p.276.

38 See e.g. Gillespie, "Reprimanding Juveniles and the Right to Due Process" (2005) 68 Modern Law Review 1006.

39 See Engel v Netherlands (No.1) (1976) 1 EHRR 647 at para.85; Benham v UK (1996) 22 EHRR 293 and Brown v UK (1998) 28 EHRR CD 233.

40 Ibbotson v UK (1999) 27 EHRR CD 332. 
It is unfortunate that the House of Lords, in the Durham Constabulary case, chose not to revisit this important point, as it deserves to be subjected to closer scrutiny. Let us take the (admittedly more extreme) example of imprisonment. The incarceration of offenders may serve a variety of functions, and the imposition of a custodial sentence can be justified on a number of grounds. Indeed, as a result of recent changes to the sentencing structure, a court which considers only one justification in determining a sentence would now be failing in its legal duty. ${ }^{41}$ In the case of offenders who are thought to be dangerous, the main reason for imposing imprisonment will usually be for the protection of the public, but can it sensibly be argued that a longer than normal custodial term is not inherently punitive in nature ${ }^{42}$ It is easier to see the problems of competing objectives in relation to custodial sentences, but in the Durham Constabulary case Lady Hale recognised that:

"[Reprimands] and final warnings do carry consequences. Individually each of these can be explained away as preventive rather than punitive. Cumulatively, however, they amount to a considerable modification of the child's legal status. He and many others might consider it punitive. He faces a higher penalty should he offend again, he must notify the police of his whereabouts for some time, and his details are on a computer to which a very large number of people have access, albeit under carefully controlled circumstances... The domestic characterisation of a measure as preventive rather than punitive cannot always be the end of the story. Nor can the perception of an offender and his family that he is being punished, as well as being helped, be completely irrelevant to the interpretation of an autonomous convention concept." 43

Our criticism relates not just to this case but to a substantial body of case law which, for pragmatic reasons, has limited the situations where a measure which carries some negative consequence for an individual after that individual admits to or is convicted of a criminal offence, is adjudged to be punitive. The effect of this jurisprudence is that human rights protection is available only in respect of those measures which are primarily punitive in effect. If the measure is judged to be essentially rehabilitative, or preventive, then it is not regarded as punitive. It is submitted that this reasoning is far too simplistic. Punishment is obviously an important response to the problem of offending, but the diversity of sanctions available within the criminal justice process necessitates a broader conception of what is "punitive". A measure may be punitive in its effect, even where its primary justification is utilitarian

41 The Criminal Justice Act 2003, s.142. See von Hirsch and Roberts, "Legislating Sentencing Principles: the Provisions of the Criminal Justice Act 2003 Relating to Sentencing Purposes and the Role of Previous Convictions" [2004] Criminal Law Review 639; and Ashworth, "Criminal Justice Act 2003(2): Criminal Justice Reform: Principles, Human Right and Public Protection" [2004] Criminal Law Review 516. Also see the Sentencing Guidelines Council, Overarching Principles: Seriousness, 2004, para.1.2.

42 For details of the special provisions for dealing with "dangerous" offenders, see the Criminal Justice Act 2003, ss.224-229.

43 [2005] 2 All ER 369 at 394 
rather than retributive. An example of this is where a court imposes a measure on a mentally disordered offender, not as a punishment, but for the purpose of either "treating" the offender or protecting the public. Although punitive considerations are not meant to be relevant to such disposals, it can be argued that ideas of justice and proportionality ought to apply to such offenders even in the (formal) absence of punishment-related objectives. ${ }^{44}$

As Lady Hale observed in the Durham Constabulary case, the effects of the warning - the requirement that the individual has to notify the police of his whereabouts, the fact that details of the offence are available to those with access to the police national computer and the adverse consequences should he re-offend - may be regarded by many as punitive. It has been pointed out by Bagaric ${ }^{45}$ that the subjective experience of the offender cannot be the sole determinant of whether or not a measure is regarded as punitive. He gives the example of an individual who finds imprisonment preferable to life on the outside, and states that this individual's term of imprisonment none the less has to be regarded as an imposition of punishment. But, in the Durham Constabulary case, as Lady Hale acknowledged, it is not only the offender who may reasonably have regarded the sanction as punitive, as his perception of it would probably have been shared by others.

Why then do we share the belief that reprimands and warnings may involve punishment? Our notion of punitiveness is wider than that adopted by the majority of the House of Lords in the Durham Constabulary case. ${ }^{46}$ Although there are innumerable definitions, punishment has been defined by Morris as "the imposition upon a person who is believed to be at fault of something commonly believed to be a deprivation, where that deprivation is justified by the person's guilty behaviour". ${ }^{47}$ Adopting this definition, the disposal in this case clearly involved consequences for the offender which would be commonly believed to be a deprivation. These consequences included: the requirement that he notify the police of his whereabouts; that any future sentence would reflect the fact that he had been warned in the past; and (perhaps most notably) the fact that many avenues of future employment would not be open to him, as details of the offence would remain on the police national computer. Accordingly, it would be wrong not

44 See Ashworth, Sentencing and Criminal Justice (2005), p.378.

45 Bagaric, Punishment and Sentencing: A Rational Approach (2001), p.37.

46 Although, technically, Lady Hale and Lord Steyn gave assenting judgments it would appear that the reason for this was that the process lacked a necessary element of "public condemnation". Lady Hale commented [2005] 2 All ER 369 at 394 that, if this element had been present, "I would have found it difficult not to regard it as the determination of a criminal charge. The domestic characterisation of a measure as preventive rather than punitive cannot always be the end of the story."

47 Morris, "Persons and Punishments" in Grupp, (ed.), Theories of Punishment (1971), p.76. Also see Hart, Punishment and Responsibility (1968), at pp.4-5, where he states that punishment "must involve pain or other consequences normally considered unpleasant; it must be for an offence against legal rules; it must be of an actual or supposed offender for his offence; it must be intentionally administered by human beings other than the offender; [and] it must be imposed and administered by an authority constituted by a legal system against which the offence is committed" (emphasis added). 
to regard the consequences of the warning as significant, and this important point was recognised by Lady Hale.

The other requirement of Morris' definition of punishment is satisfied in that, due to the claimant's admission of the alleged conduct, and the police officer's determination that this amounted to indecent assault, it was believed that he was guilty of criminal behaviour. Incidentally, it is interesting that Morris' definition refers to someone "believed to be at fault", as opposed to actually being "at fault", in view of an observation that we make later about how diversionary approaches can assume guilt even where a suspect might have had a valid defence in law. Not all penal theorists would agree with widening the definition to include those "believed" to have broken the criminal law. Traditional retributivist justifications have concentrated on the idea of punishment being "deserved", ${ }^{48}$ so that where an individual is not actually guilty of an offence, the sanction imposed upon him cannot properly be regarded as punishment. This is not the place for a detailed discussion of either this point or the different meanings of retributivism. But, a reasonable response appears to be to define those cases where it is believed that the individual is guilty, but where this is not in fact the case, as examples of "mistaken punishment". ${ }^{49}$

Some penal theorists argue that the element of denunciation of the offending conduct plays an important role in the practice of punishment. ${ }^{50}$ The requirement is not that the individual is condemned publicly for his or her actions, but rather that the sanction has to make it clear that the conduct was unacceptable. Once again, it is unnecessary to develop this point further in relation to the Durham Constabulary case, for we think that it is axiomatic that the warning, and its attendant consequences, would have sent out a clear signal to the individual that his behaviour was unacceptable. It is interesting that few criminologists have studied how offenders perceive diversionary procedures. However, a notable exception is Lee, who argued that the process associated with police cautioning was inherently punitive and viewed as such both by offenders and the police. ${ }^{51}$ Given that the new scheme of reprimands and warnings is designed to be more intrusive than the old system of cautioning, Lee's observations would seem to have even greater force today.

48 Walker, op.cit., n.28, p.2. For a recent discussion of traditional retributive justifications and their problems, see von Hirsch and Ashworth, Proportionate Sentencing (2005), Chap.2. Also see Cottingham, "Varieties of Retribution" (1979) 29 Philosophical Quarterly 238.

49 Walker, ibid., p.2.

50 For a summary see Bagaric, op. cit., n.45, pp.34-35. See also von Hirsch, Censure and Sanctions (1993), which is discussed further in von Hirsch and Ashworth, op. cit., n.48, where it is stated (at p.17) that "punishment conveys to the actor [i.e. offender] a certain critical normative message concerning his conduct: e.g. that he has culpably harmed or risked harming someone, and is disapproved of for having done so. . . He is being confronted with disapproval in virtue of the wrongfulness of his conduct, and not solely in order to produce preventive or other societal benefits that such censure might achieve".

51 Lee, "Pre-Court Diversion and Youth Justice" in Noaks et al (eds.), Contemporary Issues in Criminology (1995). 
In the Durham Constabulary case, their Lordships appear to have confused the definition of punishment with its justification. A belief that a process or disposal which is utilitarian in character does not amount to punishment presupposes that punishment has to be retributive. This view lacks plausibility, and it must be concluded that the definition of punishment used by the House of Lords was not a neutral one. Instead of looking at the purpose of the sanction, their Lordships should have developed a more rigorous conceptual framework for determining whether or not a measure can properly be regarded as constituting punishment. It is suggested that a test which states that a measure which is primarily preventive or rehabilitative cannot be punitive is deeply flawed, and that this has the undesirable effect of limiting human rights protection to those subjected to more overt and invasive restrictions on their liberty. Moreover, a proper conception of punishment should not exclude the wider consequences of a particular sanction. For example, the restriction of a person's future employment prospects is (at least potentially) more disadvantageous than the imposition of a nominal penalty, or a fine, by a criminal court. It is particularly important that human rights are respected in the context of reprimands and warnings under the 1998 Act, in view of the fact that the government's main purpose for introducing this new statutory scheme for children and young people was to make diversion more onerous.

\section{Diversion}

In the Durham Constabulary case, Lord Bingham and Lady Hale gave detailed accounts of how the new system of reprimands and warnings came to replace the earlier practice of cautioning. ${ }^{52}$ They noted that police cautioning of young people for minor offences has a long history, and that in many cases its use was highly appropriate. Lord Bingham justified this primarily on the basis of proportionality:

"[It] has long been recognised as undesirable in many cases for young offenders to be drawn into the process of the criminal courts (including juvenile and youth courts) unless this is really necessary. So informal procedures grew up to deal with cases which were not so serious as to leave no realistic alternative to prosecution. There were always, of course, some cases which, although disclosing a breach of the criminal law, were so trivial as to be properly ignored or dealt with by way of informal and unrecorded advice or admonition. But there were other cases which were too serious to be dealt with in that way but not so serious as necessarily to call for prosecution. ${ }^{53}$ (Emphasis added)

Interestingly, this statement appears to acknowledge that the practice of cautioning young offenders, whilst diversionary in its aim, also incorporated an element of punitiveness. For, if this were not the case, why was it that

52 For a more detailed history of police cautioning see Dingwall and Harding, op. cit., n.2, pp.98-119; Easton and Piper, Sentencing and Punishment: The Quest for Justice (2005), pp.200-205 and Steer, Police Cautions - A Study in the Use of Police Discretion (1970).

53 [2005] 2 All ER 369 at 373. 
some offences were deemed too trivial for such a disposition, while others were too serious? Lord Bingham, rather uncritically, accepted the government's claim that cautioning was both a wasted opportunity to provide necessary support for young offenders, and that repeat cautioning had led to a culture where some offenders believed that they could offend with impunity. ${ }^{54}$ The new diversionary framework addressed both of these concerns. Final warnings involve a presumption that the offender will complete a rehabilitative programme ${ }^{55}$ (although in the Durham Constabulary case the youth offending team did not deem this necessary for the claimant), and the 1998 Act also limits the circumstances in which reprimands and warnings can be given more than once. ${ }^{56}$ There can be no doubt that the new framework is now more onerous than the informal, nonstatutory system that it replaced. This is not to say that the additional requirements cannot be justified, nor to suggest that they will prove ineffective in rehabilitative terms. For example, studies have been undertaken both in England ${ }^{57}$ and in Northern Ireland ${ }^{58}$ in relation to "restorative" cautioning, building on the important criminological work of Braithwaite, ${ }^{59}$ and their conclusions have led to a cautious optimism.

However, what is of relevance to this discussion is that the additional requirements make the scheme more punitive in nature. Lord Bingham's statement (above) remains valid in that a police officer, in determining whether it is appropriate to issue a reprimand or warning, will continue to judge some matters to be too trivial to merit this sanction, and others sufficiently serious that prosecution is to be favoured. ${ }^{60}$ It has been argued that diversionary strategies can provide a proportionate response to minor acts of law-breaking and that diversion, if used appropriately, can form part of a coherent, retributive sentencing strategy. ${ }^{61}$ By differentiating between

54 ibid., at 373 . See references in $n .5$ for an alternative view.

55 The Crime and Disorder Act 1998, s.66(2). S.66(3) provides that "The Secretary of State shall publish, in such manner as he considers appropriate, guidance as to (a) what should be included in a rehabilitative programme arranged for a person under subsection (2) above; (b) the manner in which any failure by a person to participate in such a programme is to be recorded; and (c) the persons to whom any such failure is to be notified."

56 The Crime and Disorder Act 1998, s.65(2) and s.65(4). There were in fact restrictions on the use of multiple cautions (albeit not in statutory form) in the Home Office Circular 18/1994 The Cautioning of Offenders. It was stated that a caution should only be used in subsequent cases if the new offence was of a trivial nature or the time span between the new offence and the previous caution suggested that the caution had had some positive impact.

57 Young and Goold, "Restorative Police Cautioning in Aylesbury - from Degrading to Reintegrative Shaming Ceremonies?" [1999] Criminal Law Review 126.

58 O'Mahony and Doak, "Restorative Justice - Is More Better? The Experience of Police-led Restorative Cautioning Pilots in Northern Ireland" (2004) 43(5) Howard Journal of Criminal Justice 484.

59 Braithwaite, Crime, Shame and Reintegration (1989).

60 Although the Crime and Disorder Act 1998 only refers specifically to situations where prosecution would be an alternative (s.65(1)), it would be practically impossible to administer a system where no cases were diverted informally: see Dingwall and Harding, op. cit., n.2, pp.98-102.

61 ibid., pp.19-25. Although it was also argued that the existing practice of diversion did not always reflect issues of culpability and/or harm. 
reprimands and warnings in terms of consequence, the new framework adds an additional tier of punishment. A police officer must now decide not only whether to divert the offender from prosecution but, if he does so, which of the options is the more appropriate. The Act stipulates that this determination is to be made on retributive grounds: "[where] the offender has not been previously reprimanded, the constable shall warn rather than reprimand the offender if he considers the offence to be so serious as to require a warning". ${ }^{62}$ Therefore, it is recognised in the legislation that warnings are more punitive than reprimands.

One of the strengths of the practice of diverting young offenders from the formal processes of trial, conviction and sentence is that it seeks to avoid the labelling process, which can lead to offenders being stigmatised and also to a deterioration of their chances of becoming law-abiding in the future. As we have observed, the policy of diversion is related to the proportionate use of the formal procedures of the criminal justice system. Clearly, a system of diversion will not inspire public confidence if it permits known offenders to re-offend with nothing more than a further caution; nor should it disregard the feelings of the victims of such offences. It could be argued that the new scheme of reprimands and warnings will lead to greater consistency in the use of diversionary measures, and that this will inspire greater public confidence than the system it replaced. In its recent reform proposals, the government has attached great importance to the need to restore public confidence in the criminal justice system. ${ }^{63}$

However, the Durham Constabulary case suggests that, to some extent, the new system may be too punitive in nature. It could be argued that a process which now requires a young person to be placed on the sex offenders register for a relatively minor offence fails to adhere to the positive value of the diversionary process. Can it really be argued that a minor offence, which did not require prosecution, should result in such a negative label being applied to the offender? If the claimant was in fact regarded as a potential danger to the public, it is questionable whether his case should have been dealt with outside the formal criminal justice system without his informed consent. If, as seems more likely from the claimant's description of his conduct, the offence was a relatively minor one, it is difficult to understand the necessity for his inclusion on the sex offenders register. Its reform of the diversion system might be seen as typical of the government's tendency, in its youth justice policies, to send out conflicting messages, and the 1998 Act has been criticised for its lack of consistency and coherence. ${ }^{64}$ The new scheme of reprimands and warnings is now "tougher" than the former system of cautioning young offenders, and this reflects the government's preoccupation with public protection and restorative justice. ${ }^{65}$

It is worth making one final comment about the new scheme. As noted earlier, the old system of cautioning required the consent of the young

62 The Crime and Disorder Act 1998, s.65(4).

63 See the "Halliday Report", Report of a Review of the Sentencing Framework for England and Wales, Making Punishments Work (2001) and the Carter Review: Correctional Services Review, Managing Offenders - Reducing Crime (2003).

64 See Fionda, op. cit., n.5.

65 See Ashworth, op. cit., n.41. 
offender and his or her parent or guardian, but the new scheme has no express requirement of consent. It could be argued that the requirement of consent was largely a formality because, if an offender admitted the alleged conduct (as the claimant did in the Durham Constabulary case), he was unlikely to withhold consent to being warned when faced with the alternative of being prosecuted. Yet, despite this argument, informed consent should be seen as an important safeguard in what amounts to an informal system of justice. ${ }^{66}$ A recurring criticism of diversionary schemes is that they confer too much discretion on the police to make decisions relating to both the guilt and the disposal of suspected offenders, and that this may compromise the rights of the accused. These concerns are substantiated by the Durham Constabulary case, where the involvement of the police in important decision-making, and in administering the warning, may have been instrumental in their failure to notify the claimant that (as a consequence of being warned) he would also be placed on the sex offenders register. As a way of ensuring that a young person's rights are protected, and that he or she is given all the relevant information relating to the process, informed consent ought to be a requirement of the reprimands and warnings scheme. The Divisional Court appeared to recognise the importance of this point, but it seems to have evaded the House of Lords. By defining the process as something other than the determination of a criminal charge, Lord Bingham was able to argue that the claimant's "fair trial rights were not engaged". ${ }^{67}$ This seems to ignore the reality of the informal system of justice which deals with diversionary measures, and it is difficult to escape the conclusion that the claimant was, in fact, dealt with by an administrative process which did not provide the usual safeguards for those accused of a criminal offence. In view of the serious consequences for the claimant resulting from a warning, it is surely sophistry to argue that there was no determination of a criminal charge because the disposal was not "punitive" in nature.

The claimant was faced with an accusation about a certain set of facts, which he accepted as true, but which he argued were trivial in nature. The House of Lords attached importance to the claimant's admission, and it was argued by Lady Hale that "once a reliable admission has been made... the decision whether or not to prosecute is for the authorities rather than the accused". ${ }^{68}$ The problem with this approach is that it ignores the fact that an accused young person may lack the expert advice that he or she would receive in the event of formal proceedings taking place. For example, a young person might admit the actual facts made in an accusation, whilst unaware of a relevant argument or defence which might have affected his or her liability or culpability had the case gone to trial. (For instance, a person might admit to the actus reus of theft without realising that there was an important issue

66 A point developed by Gillespie, op. cit., n.38, pp.1012-1015. It would also appear to breach General Assembly Resolution 40/33 (1985), Rule 11.3: "Any diversion involving referral to appropriate community or other services shall require the consent of the juvenile, or her or his parents or guardian, provided that such decision to refer a case shall be subject to review by a competent authority, upon application".

${ }^{67} R$ (on the application of $R$ ) v Durham Constabulary and another [2005] 2 All ER 369 at 385 .

68 ibid., at 394-395. 
relating to dishonesty, which might have been raised in court to negate criminal liability). In the Durham Constabulary case, the clamant may (arguably) have admitted to the facts of the alleged conduct, whilst unsure whether the behaviour in question did, in fact, amount to an indecent assault. A criminal court does not permit a police officer to be the sole determinant of such questions, but the informal system of reprimands and warnings appears to do so. This may serve the interests of administrative convenience and economy, but it raises serious concerns about the fairness of the new system.

\section{Conclusion}

Although the actual decision of the House of Lords in the Durham Constabulary case invites criticism, there are some promising signs in the judgments that the British courts may yet become less deferential to Parliament when deciding on human rights issues. Lady Hale emphasised that "diversion is not to be bought at the cost of basic fairness to the child", ${ }^{69}$ and she identified an important issue in asking "whether it is fair to subject a child to the formal diversion process with mandatory legal consequences without first obtaining his informed consent"..$^{70}$ Lady Hale confessed also to:

"[Grave] doubts about whether the statutory scheme is consistent with the child's rights under the international instrument dealing with children's rights. The rigidity of the scheme undermines the emphasis given to diverting children from the criminal justice system, propels them into it and on a higher rung of the ladder earlier than they would have previously arrived there, and thus seriously risks offending against the principle that intervention must be proportionate both to the circumstances of the offender and of the offence". ${ }^{71}$

In view of Lady Hale's cogent criticisms of both the new statutory scheme and the police's handling of the case, ${ }^{72}$ it is surprising that she concluded ("not without considerable misgivings") ${ }^{73}$ that there had not been a breach of the claimant's rights under the ECHR. This article has suggested that the reasoning of the House of Lords, in reaching this conclusion, is far from convincing. It does little to address the concern that the government, by means of some important provisions in the Crime and Disorder Act 1998, has created new procedures which have circumvented its own human rights legislation. It has been discussed elsewhere whether anti-social behaviour orders are consistent with a commitment to human rights. ${ }^{74}$ This article has raised similar concerns about the new system of reprimands and warnings. The implications of being reprimanded or warned are now more serious for

69 ibid., at 389.

70 ibid., at 389.

71 ibid., at 393 .

72 ibid., at 393.

73 ibid., at 395.

74 Ashworth, op. cit., n.10, where he states (at p.289): "It is plain that in introducing the anti-social behaviour order. . . the government intended to sail as close to the wind as possible"; and at (p.290) he asks whether the government in developing this order has "crossed the boundary from avoidance to evasion of its responsibility to uphold human rights". 
young people than under the old system of cautioning, with more punitive consequences for the suspect. By accepting a narrow interpretation of what amounts to a "criminal charge", and of what is meant by "punishment", the House of Lords has missed a valuable opportunity to subject the government's reprimands and warnings scheme to a more critical scrutiny. 